\title{
UPAYA MENINGKATKAN HASIL BELAJAR PKN SISWA KELAS V.B SD NEGERI 06 PAYARAMAN MELALUI PEMBELAJARAN KOOPERATIF DENGAN MODEL PENUGASAN
}

\author{
SOHIB \\ (SDN 06 PAYARAMAN)
}

\begin{abstract}
ABSTRAK
Tujuan penelitian ini yaitu untuk meningkatkan hasil belajar siswa PKn melalui model Pembelajaran Penugasan. Proses pembelajaran mata pelajaran PKn terjadi secara konvensional-tradisionil, hal ini mengakibatkan hasil pembelajaran belum sesuai dengan yang diharapkan. Lokasi Penelitian adalah SD Negeri 06 Payaraman beralamat di Jalan Raya KM 63 Desa Serikembang Kec. Payaraman Kabupaten Ogan Ilir Provinsi Sumatera Selatan. Metode pengumpulan data dengan cara observasi dan tes terhadap siswa. Penelitian tindakan kelas dilaksanakan selama dua siklus, dengan setiap siklus diadakan selama tiga kali pertemuan. Proses pembelajaran dengan menggunakan model pembelajaran Penugasan. Sebagai alat pengumpul data adalah lembar observasi yang telah diisi oleh observer, dengan langkah-langkah perencanaan tindakan, pelaksanaan tindakan, observasi, evaluasi dan refleksi untuk setiap siklus. Siklus pertama didapat nilai ulangan harian ratarata $69,35 \%$ sedangkan pada siklus ke dua diperoleh nilai rata-rata ulangan 78,05 $\%$. Telah terjadi peningkatan hasil nilai ulangan harian rata-rata sebesar 8,7 atau 50\%. Dapat disimpulkan bahwa hasil belajar PKn siswa mengalami peningkatan secara signifikan pada semua indikator setelah melalui model pembelajaran Penugasan dilaksanakan yang berujung pada peningkatan hasil belajar yang signifikan.
\end{abstract}

Kata Kunci: Model Penugasan, Perundang-undangan Tingkat Pusat dan Daerah

\section{PENDAHULUAN}

Motivasi belajar tidak akan terbangun apabila siswa masih merasa kesulitan dalam menerima pelajaran $\mathrm{PKn}$, PKn dianggap sebagai pelajaran yang membosankan. Sehingga jangan disalahkan apabila disetiap jam pelajaran PKn siswa cenderung merasa enggan dan malas. Untuk mengantisipasi hal tersebut perlu ada solusi dalam penyampaian mata pelajaran PKn dengan menggunakan berbagai cara yang menarik yang ada kaitannya dengan kehidupan sehari-hari. Sunardi (2006:13) menyarankan untuk mengupayakan agar pelajaran PKn menyenangkan anak, sampaikan materi yang sudah dikenal anak hingga anak percaya diri. 
Tugas guru yang utama adalah mengajar, yaitu menyampaikan atau mentransfer ilmu kepada anak didiknya. Oleh karena itu seorang guru sekolah dasar (SD) dituntut untuk menguasai bidang studi yang dia ajarkan. Namun hasil perolehan nilai mata pelajaran dalam keyataannya belum memenuhi standar, tidak terkecuali untuk mata pelajaran PKn. Berdasarkan pengalaman peneliti hal ini disebabkan oleh, teknik mengajar yang masih relatif monoton. Sejauh ini pembelajaran PKn di kelas mayoritas masih dilaksanakan dengan metode ceramah. Hal ini tidak menutup kemungkinan menyebabkan interaksi belajar mengajar yang lebih melemahkan motivasi belajar siswa.

Pembelajaran PKn haruslah lebih berkembang, tidak hanya terfokus pada kebiasaan dengan strategi atau urutan penyajian sebagai berikut : diajarkan definisi, diberikan contoh-contoh dan diberikan latihan soal. Hal ini sangat memungkinkan siswa mengalami kesulitan dalam menerima konsep yang tidak berasosiasi dengan pengalaman sebelumnya. Dalam latihan soal sebaiknya dihadapi bentuk soal cerita yang mungkin terkait dengan terapan PKn atau kehidupan sehari-hari. (Guntur Sumilih 2002: 103)

Proses belajar mengajar merupakan suatu proses yang mengandung serangkaian perbuatan guru dan peserta didik atas dasar hubungan timbal balik yang berlangsung dalam kegiatan belajar untuk mencapai tujuan tertentu. Interaksi atau hubungan timbal balik antara guru dan peserta didik itu merupakan syarat utama bagi berlangsungnya proses belajar mengajar. Oleh karena itu seiring dengan perkembangan ilmu pengetahuan dan kemajuan teknologi, paradigma pembelajaran di persekolahan banyak mengalami perubahan, terutama dalam pelaksanaan proses pembelajaran dari yang bersifat behavioristik menjadi konstruktivisme; dari yang teacher-concered menjadi student-concered.

Hal ini artinya bahwa guru tidak semata-mata hanya memberikan pengajaran yang sifatnya teks book kepada siswa. Siswa harus mampu membangun pengetahuan dalam alam pikirannya. Guru dapat membantu proses ini dengan caracara pembelajaran yang membuat informasi menjadi sangat bermakna dan sangat relevan dengan kebutuhan siswa, yaitu dengan cara memberikan kesempatan kepada siswa untuk menemukan atau menerapkan sendiri ide-ide dan dengan mengajak siswa agar dengan menyadari dan dengan sadar menggunakan strategistrategi mereka sendiri untuk belajar. Sehingga, keberhasilan proses pembelajaran yang dilakukan benar-benar memenuhi persyaratan yang telah diatur dalam kurikulum tingkat satuan pendidikan dan harus selaras pula dengan tujuan yang hendak dicapai. Akan tetapi hasil yang dicapai oleh peserta didik kelas V.B di SD Negeri 06 Payaraman masih belum mencapai target yang diharapkan sesuai Standar ketuntasan belajar minimum yang telah ditetapkan melalui penghitungan KKM terutama untuk mata pelajaran PKn kelas V.B di SD Negeri 06 Payaraman. Berdasarkan kondisi tersebut maka ada indikasi bahwa proses pembelajaran kurang berhasil. Oleh karena itulah penulis tertarik untuk melakukan penelitian terhadap prestasi belajar peserta didik dengan melaksanakan pembelajaran kooperatif dengan model Penugasan. 
Model Penugasan yang menjadi pilihan peneliti dikarenakan berdasarkan hasil studi pendahuluan diketahui bahwa gurulah yang lebih banyak aktif dibandingkan dengan peserta didik, artinya guru hanyalah memberikan informasi (transfer of learning), lebih banyak melakukan aktivitas dibandingkan dengan peserta didik. Dengan kata lain guru lebih banyak menggunakan pendekatan mengajar yang bersifat eksipotori, akibatnya prestasi belajar peserta didik belum maksimal.

Berdasarkan uraian diatas peneliti menentukan judul penelitian ini adalah "Meningkatkan Hasil Belajar PKn Siswa Kelas V.B Di SD Negeri 06 Payaraman Melalui Pembelajaran Kooperatif Dengan Model Penugasan". Tujuan yang ingin dicapai dalam penelitian ini adalah: untuk menyelidiki apakah melalui pembelajaran kooperatif dengan model penugasan dapat meningkatkan hasil belajar PKn siswa kelas V.B SD Negeri 06 Payaraman.

\section{Hasil Belajar}

Hasil belajar adalah kemampuan atau prestasi yang siswa capai setelah melalui proses belajar mengajar. Sudjana (2011: 22) menyatakan bahwa hasil belajar adalah kemampuan-kemampuan yang dimiliki siswa setelah ia menerima pengalaman belajarnya. Hasil belajar merupakan suatu bukti bahwa seseorang telah belajar, yang dilihat dari perubahan tingkah laku pada orang tersebut dari tidak tahu menjadi tahu dan tidak mengerti menjadi mengerti (Hamalik 2014: 30). Hasil belajar merupakan perubahan tingkah laku yang terjadi pada seseorang yang menerima pembelajaran, dari kondisi tidak tahu dan tidak mengerti akan sesuatu, karena ia belajar sehingga menghasilkan pengetahuan dan mengerti tentang hal yang ia pelajari.

Menurut Purwanto (2013: 46) menyatakan bahwa hasil belajar adalah hasil yang dicapai dari proses belajar mengajar sesuai dengan tujuan pendidikan. Benjamin S. Bloom memaparkan bahwa hasil belajar diklarifikasikan menjadi 3 ranah yaitu ranah kognitif, ranah afektif dan ranah psikomotor (Sudjana, 2010: 22). Dengan demikian, hasil belajar yang baik jika terdapat perubahan tingkah laku yang diukur dengan ranah kognitif, ranah afektif dan ranah psikomotor.

\section{Model Penugasan}

Model Penugasan dikembangkan oleh Spencer Kagan (1992), yakni model yang memberikan kesempatan kepada siswa untuk saling membagi ide-ide dan mempertimbangkan jawaban yang paling tepat. Menurut Mulyana dan Johan Permana H (2001: 24), metode pemberian tugas atau penugasan diartikan sebagai suatu cara intraksi belajar mengajar yang ditandai dengan adanya tugas dari guru yang dikerjakan peserta didik di sekolah ataupun di rumah secara perorangan atau kelompok. Metode resitasi tidak sama dengan pekerjaan rumah tetapi lebih luas dari itu. Metode resitasi merangsang peserta didik untuk aktif lebih belajar secara 
individu atau kelompok. Tugas atau resitasi bias dilaksanakan di rumah, di sekolah, di perpustakaan, dan tempat lainnya. Uraian diatas menggambarkan bahwa resitasi sebagai metode belajar dan mengajar merupakan sebuah upaya pembelajaran siswa dengan cara memberikan tugas penghafalan, pengujian, dan pemeriksaan atas diri sendiri atau menampilkan diri dalam menyampaikan pelajaran atau melakukan kajian maupun uji coba sesuai dengan tuntutan dalam rangka untuk merangsang siswa agar lebih aktif belajar kreatif dan pemikiran siswa semakin kreatif, baik secara perorangan maupun kelompok, menumbuhkan kebiasaan untuk belajar mencari dan menemukan, mengembangkan keberanian dan tanggung jawab diri sendiri, dan memungkinkan untuk memperoleh hasil yang permanen.

\section{METODE}

Lokasi Penelitian adalah SD Negeri 06 Payaraman beralamat di Jalan Raya KM 63 Desa Serikembang Kec. Payaraman Kabupaten Ogan Ilir Provinsi Sumatera Selatan. Subyek penelitian ini yaitu seluruh siswa kelas V. B SD Negeri 06 Payaraman. Pengumpulan data dilakukan dengan menggunakan observasi dan tes yang digunakan dalam penelitian ini terdiri atas: 1) Lembar observasi, yaitu data dikumpulkan dengan cara mengamati proses pembelajaran siswa selama proses pembelajaran dengan menggunakan pembelajaran Penugasan, 2) Tes, yaitu indicator tes digunakan untuk mengumpulkan data tentang hasil belajar siswa setelah proses pembelajaran dengan model pembelajaran pembelajaran Penugasan, dan 3) Tes yang digunakan oleh peneliti adalah tes tertulis dalam bentuk uraian. Teknik analisa data menggunakan rumus teknik proporsi dengan rumus : $\mathrm{D}=[\mathrm{A}$ / N ] x $100 \%$, Di mana (D : prosentase siswa yang tuntas, A : Jumlah siswa yang tuntas, dan N :Jumlah seluruh siswa (Sudjana, 2010). Hasil analisis data disajikan dalam bentuk data, table dan grafik untuk memudahkan dalam membaca data dan memprediksi kesimpulan apa yang diambil dari penelitian yang dilakukan.

\section{HASIL PENELITIAN DAN PEMBAHASAN}

\section{Deskripsi Per Siklus}

Selama kegiatan pembelajaran berlangsung dari siklus pertama sampai siklus ke tiga yang dilakukan pengamatan terhadap aktivitas belajar siswa yang dilakukan oleh guru, bekerjasama dengan teman sejawat menggunakan lembar observasi yang telah disediakan peneliti, diperoleh hasil sebagai berikut : 
CIVICS EDUCATION AND SOCIAL SCIENSE JOURNAL(CESSJ)

Volume 3 Nomor 1 Edisi Bulan Juni 2021

Tabel 1. Tingkat Aktivitas Belajar Siswa Kelas V.B

\begin{tabular}{|l|l|l|l|}
\hline No. & \multicolumn{1}{|c|}{ Keaktifan siswa } & Siklus I & \multicolumn{1}{c|}{ Siklus II } \\
\hline 1. & Terbaik & - & $\mathbf{1}$ \\
\hline 2. & Sangat Baik & - & $\mathbf{5}$ \\
\hline 3. & Baik & $\mathbf{8}$ & $\mathbf{1 3}$ \\
\hline 4. & Cukup & $\mathbf{1 2}$ & $\mathbf{1}$ \\
\hline 5. & Kurang & - & - \\
\hline & Jumlah & $\mathbf{2 0}$ & $\mathbf{2 0}$ \\
\hline
\end{tabular}

Tabel 2. Daftar Nama dan Nilai Siswa Kelas V.B

\begin{tabular}{|c|l|l|l|}
\hline No & \multicolumn{1}{|c|}{ Nama Siswa } & Siklus I & Siklus II \\
\hline 1 & Adil Isahdan Purba & 60 & 75 \\
\hline 2 & Ardiansyah & 66 & 75 \\
\hline 3 & Chitra Desti Permata & 62 & 69 \\
\hline 4 & Danda Herlian & 68 & 77 \\
\hline 5 & Delan Pratama & 70 & 80 \\
\hline 6 & Dillan Anisa & 67 & 75 \\
\hline 7 & Divo Perdana Hedrian & 77 & 82 \\
\hline 8 & Dita Mesi Putri & 67 & 77 \\
\hline 9 & Hendri & 74 & 81 \\
\hline 10 & Husni Mubarok & 67 & 75 \\
\hline 11 & Ikbal Putra & 76 & 83 \\
\hline 12 & Jeri & 66 & 77 \\
\hline 13 & Kevin Hermansyah Putra & 65 & 76 \\
\hline 14 & Laura & 67 & 73 \\
\hline 15 & Muhammad Nabil & 65 & 78 \\
\hline 16 & Naufal Pranajaya & 71 & 78 \\
\hline 17 & Nur Alimi & 71 & 77 \\
\hline 18 & Rahma Febriyanti & 74 & 79 \\
\hline 19 & Rahyu Oktavianisa & 71 & 83 \\
\hline 20 & Raja Wira Kusuma & 83 & 91 \\
\hline & Jumlah & 1387 & 1561 \\
\hline & Rerata & 69,35 & 78,05 \\
\hline
\end{tabular}


Dari data di atas ternyata diperoleh jumlah siswa yang keaktifannya mengalami peningkatan yang sangat signifikan, hal ini menunjukkan bahwa dalam pelaksanaan pembelajaran telah terjadi perubahan aktivitas proses belajar mengajar. Pada setiap akhir siklus dilakukan tes berupa ulangan harian yang bertujuan untuk mengetahui tingkat keberhasilan tindakan perbaikan pembelajaran yang telah dilakukan.

Berdasarkan tabel di atas pada siklus pertama didapat nilai ulangan harian rata-rata 69,35 sedangkan pada siklus ke dua diperoleh nilai rata-rata ulangan 78,05 . Telah terjadi peningkatan hasil nilai ulangan harian rata-rata sebesar 8,7 atau $45 \%$, hal ini menunjukkan bahwa dalam pelaksanaan perbaikan pembelajaran terjadi perubahan aktivitas dan hasil belajar siswa.

Perubahan yang terjadi baik terhadap siswa maupun guru itu sendiri terutama dalam kegiatan belajar mengajar yang selama ini hanya sebagai pemberi informasi namun setelah dilaksanakan perbaikan pembelajaran guru dapat memperbaiki kelemahan-kelemahannya dalam mengajar, sedangkan pada siswa terjadi perubahan dalam bentuk aktivitas yang berimbas dengan meningkatnya pemahaman dan hasil belajar.

\section{Pembahasan Per Siklus}

Berdasarkan hasil pengamatan tindakan perbaikan dari siklus I dan siklus II dengan menggunakan instrumen berupa lembar observasi dan alat tes berupa soal-soal, tujuan perbaikan telah tercapai dengan melihat hasil penilaian proses dan penilaian akhir pada siklus ke dua.

1. Siklus I

Nilai ulangan harian rata-rata mendapat nilai 69,35 dari jumlah siswa berarti belum tercapai ketuntasan belajar siswa. Hal ini karena beberapa kendala dan kelemahan dalam melaksanakan pembelajaran yaitu antara lain aktivitas belajar siswa masih rendah karena suasana belajar kurang menyenangkan dalam menyelesaikan tugas guru tidak memberikan atrahan, bimbingan dan petujuk yang jelas kepada siswa, kurangnya motivasi siswa dalam proses pembelajaran, hanya beberapa kelompok saja yang aktif bekerja, yang lainnya ribut dan mengganggu temannya.

2. Siklus II

Nilai ulangan harian rata-rata 78,05 dari jumlah siswa berarti telah tercapai ketuntasan belajar. Pada siklus kedua perbaikan pembelajaran dilaksanakan dengan mengacu pada kelemahan-kelemahan dan kendala-kendala yang terjadi pada siklus ke dua dengan merubah tindakan-tindakan yang bertujuan untuk perbaikan pada siklus kedua, siswa telah memahami materi yang diajarkan, hal ini terlihat dari peningkatan hasil belajar, semua kelompok yang sudah maju dan menyampaikan hasil diskusinya diskusinya, ketua kelompok benar-benar berperan penting. 
CIVICS EDUCATION AND SOCIAL SCIENSE JOURNAL(CESSJ)

Volume 3 Nomor 1 Edisi Bulan Juni 2021

\section{SIMPULAN}

\section{Kesimpulan}

Berdasarkan pemasalahan yang telah dibahas maka kesimpulannya sebagai berikut : pembelajaran kooperatif melalui model penugasan dapat meningkatkan hasil belajar PKn siswa kelas V.B di SD Negeri 06 Payaraman.

\section{Saran}

Adapun saran yang dapat diberikan adalah :

1. Dalam setiap pembelajaran sebaiknya guru menggunakan strategi, metode dan media yang bervariasi sesuai dengan tujuan, kondisi dan materi pelajaran.

2. Dengan adanya perbaikan proses pembelajaran guru dapat mengetahui kelemahan dan kendala yang dihadapi dilapangan sehingga dapat melaksanakan perbaikan pembelajaran.

\section{REFERENSI}

Dimyati, Mudjiono. (2006). Belajar dan Pembelajaran. Jakarta: Rineka Cipta.

Djamarah, Syaiful Bahri. (1994). Psikologi Belajar. cet. Ke-3, Jakarta: Rineka Cipta.

Guntur Sumilih. (2002). Belajar dan Pembelajaran. Jakarta: Rineka cipta

Hamalik, Oemar. (2014). Kurikulum dan Pembelajaran. Jakarta: Bumi Aksara.

Mulyani Sumantri \& Johan Permana, H. (2001). Strategi Belajar Mengajar. Bandung: CV. Maulana

Purwanto. (2013). Evaluasi Hasil Belajar. Yogyakarta: Pustaka Pelajar.

Sudjana, Nana. (2010). Dasar-dasar Proses Belajar Mengajar. Bandung: Sinar Baru Algensindo.

Sudjana, Nana. (2011). Penilaian Hasil dan Proses Belajar Mengajar. Bandung: PT. Rosda Karya.

Sunardi. (2006). Mengakrabkan PKn Pada Anak. Yogyakarta: Kedaulatan Rakyat. 